IRA-International Journal of Management \&

Social Sciences

ISSN 2455-2267; Vol.17, Issue 02 (Q.2 2021)

Pg. no. 10-28.

IRA Academico Research

\title{
Analysis of Impacts of Working Capital Management Practices on Financial Performance of Small and Medium Enterprises (Juakali) in Mandera County, Kenya
}

\author{
Mariam Sheikh Omar ${ }^{1 \#}$, Dr. Martin Onsiro Ronald ${ }^{2}$, Njagi Gilbert Nyaga (CPA) ${ }^{3}$ \\ ${ }^{1}$ School of Business Studies, Mount Kenya University. Kenya. \\ ${ }^{2}$ Deputy Director School of postgraduate, Mount Kenya University. Kenya. \\ ${ }^{3}$ Lecturer, School of Business Studies, Mount Kenya University. Kenya.
}

\#corresponding author

Type of Work: Peer Reviewed.

DOI: https://dx.doi.org/10.21013/jmss.v17.n2.p1

\section{How to cite this paper:}

Omar, M.S. et al (2021). Analysis of Impacts of Working Capital Management Practices on Financial Performance of Small and Medium Enterprises (Juakali) in Mandera County, Kenya. IRAInternational Journal of Management \& Social Sciences (ISSN 2455-2267), 17(2), 10-28. DOI: https://dx.doi.org/10.21013/jmss.v17.n2.p1

(C) IRA Academico Research.

(c) EY-NC This work is licensed under a Creative Commons Attribution-NonCommercial 4.0 International License subject to a proper citation to the publication source of the work.

Disclaimer: The scholarly papers as reviewed and published by IRA Academico Research are the views and opinions of their respective authors and are not the views or opinions of IRA Academico Research. IRA Academico Research disclaims any harm or loss caused due to the published content to any party.

IRA Academico Research is an institutional publisher member of Publishers International Linking Association Inc. (PILA-CrossRef), USA. IRA Academico Research is an institutional signatory to the Budapest Open Access Initiative. Hungary advocating the open access of scientific and scholarly knowledge. IRA Academico Research is a registered content provider under Open Access Initiative Protocol for Metadata Harvesting (OAI-PMH).

The journal is indexed \& included in WorldCat Discovery Service (USA), CrossRef Metadata Search (USA), WorldCat (USA), OCLC (USA), Open J-Gate (India), EZB (Germany) Scilit (Switzerland), Airiti (China), Bielefeld Academic Search Engine (BASE) of Bielefeld University, Germany, PKP Index of Simon Fraser University, Canada. 


\section{ABSTRACT}

The main purpose of this study was to analyzing working capital management practices on the performance of Small Medium Enterprises (Juakali) and develop instruments that may be used to assess and improve the performance in a business environment to enhance sustainable growth. The study was guided by the following four research objectives: to analyze the cash management practices, to examine the payables management practices, to assess the receivables management practices and to investigate the inventory management practices on the performance of small and medium enterprises in Mandera County. The research was carried out through a descriptive survey research design. The target population was six hundred (600) SMEs from the different Juakali sectors. The study revealed that the key performance indicator utilized by SMEs in Mandera County was customer satisfaction. The outcomes showed that in Mandera County SMEs performance was generally not good. The study concludes that cash management practices adopted by SMEs affected their performance and recommends better cash management ought to be adopted by SMEs to enhance their performance in Mandera County Kenya.

Keywords; Capital Management practices, Small and Medium-Sized Enterprises, Financial Performance, Working capital management, and Descriptive Survey.

\section{Background to the Study}

The world globally, regionally and locally has indicated great concern on SME business performance and growth. Previous reports indicate that SMEs are the backbone of our economy worldwide yet many have either collapsed or are on the verge of failing. According to a World Bank Economic Report (2014), the majority of emerging economies boast of over $40 \%$ SMEs. SMEs have a notable effect on resource utilization and distribution, job creation, government revenue generation, as well as income stability (Fida, 2008). In many developed countries, SMEs employ about two-thirds of their population and a case in point is German where SMEs account for more than $85 \%$ of GDP (German Economic Report, 2015).

However, this approach has not yielded a lot in Nigeria and SME growth is still a big challenge. In Algeria, SME growth has received significant support from the government according to the Algerian Ministry for Industry Baseline Survey (2010). SMEs are more prominent and established in Ghana contributing to over $72 \%$ of the country's GDP and they represent over one thousand businesses in the capital (Abor and Quartey, 2010). In Kenya, the SMEs (Juakali) are easy to start considering the highly creative and innovative nature of Kenyans. However, considering the circumstance in most developing countries like Kenya, several challenges have to be overcome to see SMEs flourish and reap great returns as anticipated (World Bank Economic Report, 2015). All their resources go down the drain from the fallen investment.

However, in Kenya, specific research studies exclusively on the influence of WCM on the corporate financial performance of SMEs (Juakali) are very scanty, in particular for the case of Mandera Sub-County, Kenya. A study by (Smallbone, 2001)to establish the role of SMEs in economic growth indicated countries with a large share of SMEs employment have higher economic growth than their counterparts. Small and Medium Enterprises, in Kenya, are generally acknowledged as vital and significant contributors to economic development through their perceived critical role in providing job opportunities, poverty reduction, and entrepreneurship development and their acting as intermediaries in trade. This agrees with a study of the UK that SMEs, make a major contribution to the health of the economy and help to diversify opportunity in the society as stated by (Neumark, 2011).

\section{Financial Performance}

Financial performance is the process of weighing how worth the firms' policies and it is the operation in cash term.it can also determine firm financial performance using profitability and liquidity, profitability is measured through return on assets (ROA), return on equity (ROE), operating profit margin and net income. The liquidity of the firm is determined by the ability of the business to meet financial needs without interfering with the owner's equity. The liquidity of the firm is calculated by the current asset over the current liabilities.

Financial performance is an analysis used to observe which company has implemented the rules of financial implementation properly and correctly (Fahmi, 2014). Financial performance can also be described as the extent to which the financial goal of a firm is being or has been accomplished. It is the process of measuring the results of an organization's policies and operations in monetary terms. It measures the overall financial health of a firm over a given period. Financial performance is a way to satisfy investors and can be represented by profitability, growth and market value (Cho \&Pucik, 2005). These three aspects complement each other. Profitability measures a firm's past ability to generate returns (Glick, Washburn \& Miller, 2005). The growth demonstrates a 
firm's past ability to increase its size. Increasing size, even at the same profitability level, will increase its absolute profit and cash generation. The larger size also can bring economies of scale and market power, leading to enhanced future profitability.

\section{Working Capital Management}

Working Capital Management is concerned with the problems that arise in attempting to manage the Current Assets, the Current Liabilities and the interrelationship that exists between them. Current Assets are those assets that in the ordinary course of business can be or will be converted into cash within one year without undergoing a diminution in value and without disrupting the operations of the firm. Current liabilities are those liabilities that are intended at their inception, to be paid in the ordinary course of business, within a year, out of current assets or earnings of the concern.

Global Research studies have been undertaken on WCM in India, Pakistan, Mauritian, U.K, the US, and Belgium, to identify the push factors for firms to adopt good WCMPs and to investigate the association between WCMPs and profitability of both SMEs and LSEs. According to a World Bank Economic Report (2014), the majority of emerging economies boast of over $40 \%$ SMEs. SMEs have a notable effect on resource utilization and distribution, job creation, government revenue generation, as well as income stability (Fida, 2008). In many developed countries, SMEs employ about two-thirds of their population and a case in point is German where SMEs account for more than $85 \%$ of GDP (German Economic Report, 2015).

Simidi and Duncan (2017) studied the effects of working capital management on the financial performance of energy and petroleum companies listed at the Nairobi securities exchange and established that Working Capital Management influences the Return on Assets significantly. 17.8\% of the variations in profitability were influenced by variations in Working Capital Management. The study establishes that the influence of Working Capital Management on profitability is statistically significant. The study finds weak negative associations between profitability and inventory conversion period, accounts collection period, accounts payable period and cash conversion cycles. The study establishes that the negative relationships between the accounts payable period, cash conversion cycle and profitability are statistically significant. The relationships between accounts collection period, inventory conversion period and performance are not statistically significant.

In Mandera, SMEs has an important role because it creates job opportunity and reduces poverty level. Statistics indicate that three out of five businesses fail within the first few months of operation (KNBS 2007).

\section{Juakali}

In response to job and wealth creation, several studies and reports (Holmes, McCord, Hagen-Zanker, Bergh, \&Zanker, 2013; Katua, 2014) advocate for policies and interventions that would continue to create favourable environments for business start-ups and/or self-employment. It has also been documented in extant literature that in Africa, over 22 per cent of the working-age populace start new businesses (Copley, 2017) and through such businesses, a significant number of people create or get employment. This implies that the share of informal and/or small enterprise category employment exceeds that of large industries in Africa. Holmes et al. (2013) assert that entrepreneurship is a well-known source of employment creation, ensures stability in countries and helps reduce poverty. In the same vein, Atiase, Mahmood, Wang and Botchie (2017) argue that entrepreneurship contributes to the gross domestic product (GDP).

In developing countries, non-agricultural micro-sized informal enterprises known as the Juakali sector in Kenya are known to create employment and income generation opportunities. Many unknown barriers continue to impact the effective and efficient development of the aforementioned enterprises (Eric, Christine \& Krishna 2018). In their study, Eric, Christine and Krishna (2018) observed that some socio-demographic variables such as age, education and marital status have an impact on entrepreneurial activities in the Juakali sector. However, not much is known on the effects of working capital management on the financial performance of SMEs in Mandera County one of the marginalised areas in Kenya an area the current study seeks to address.

\section{Statement of the Problem}

SMEs contribute to the growth of the economy in many ways such as employment generation, new venture development and opening up new avenues for growth in the economy. However, the full potential has been hampered by poor accounting and financial management practices as one of the factors contributing to the massive failure of SMEs in the short run this is according to the United Nations Millenium Declaration (2005). According to (Gaskill 1993) argued that finance and financial management practice is one of the twelve competency areas for small business success. Efficient management of working capital is a fundamental part of the strategy of any SME that leads to sustainable growth. 
KNBS, (2007) has shown that $60 \%$ of SMEs fail within the first few months of operation as a result of inadequate proper working capital management skills. The failure of these SMEs is not only evidenced in Kenya but also in the global arena.

The major problem that arises is how working capital management practices affect the financial performance of SMEs. Most Small and Medium Enterprises face challenges in balancing between surplus and shortage of working capital. As a result, these firms have been experiencing slow growth because of the inability to pay daily expenses of their operations and difficulty to exploit new markets and undertake profitable projects due to shortage of working capital mainly because of poor working capital management. (Padachi, 2006).

The Mandera County government has put measures to strengthen SMEs and ensure they grow to be key industries tomorrow (Kenya Vision 2030, 2007). Previous governments have more or so made the same promise out of which nothing much has been achieved.

The challenge then becomes, why has this not been achieved? Are SMEs performing as anticipated? What are the factors inhibiting their growth? Is access to credit the only determinant as according to Gustav (2010), or are there other major determinants worth noting and looking at? For these and many other reasons, the identification of the determinants of SME business growth is very important.

Against such a background the researcher notes it is important and of great necessity to assess, evaluate and ascertain how working capital management influence performance SME business growth in Mandera County, Kenya.

\section{Objectives of the study \\ General Objective}

The main objective of this study was to analyze the working capital management on the performance of SMEs in Mandera County.

\section{Specific Objectives}

This study was also guided by the following specific objective;

i. To evaluate the effects of cash management practice on the performance of small and medium enterprises in Mandera County

ii. To examine the effects of payables management practice on the performance of small and medium enterprises in Mandera County

iii. To assess the effect of receivables management practice on the performance of small and medium enterprises in Mandera County

iv. To investigate the effect of inventory management practice on the performance of small and medium enterprises in Mandera County

\section{Research Questions}

i. What is the effect of cash management practice on the performance of small and medium enterprises in Mandera County?

ii. Is there an effect of payables management practice on the performance of small and medium enterprises in Mandera County?

iii. What is the effect of receivables management practice on the performance of small and medium enterprises in Mandera County?

iv. How does inventory management practice affect the performance of small and medium enterprises in Mandera County?

\section{Significance of the Study}

The findings of the study were expected to be of value to the management of SMEs (Juakali) who would be able to know areas of working capital that are critical to the business.

The findings of the study were also expected to be of value to the government and business support groups which can benefit as they had a basis to create solutions to working capital challenges facing SMEs (Juakali) in Kenya, bearing in mind the fact that SMEs are important to the growth of any economy. 
Lending institutions also stand to benefit from this research. Sources of funds are a component of working capital. This study will serve as a basis for financial institutions to do further research and come up with products that can meet the working capital needs of the SME sector.

The academia and researchers will also find the research findings useful in enhancing their knowledge about efficient working capital management and hence improve their understanding of the research area better. It can open more research gaps which is an avenue for further studies.

\section{Scope of the Study}

The study focused on Juakali SMEs registered and operating in Mandera County Kenya but was limited to a target population of 600. A simple random sampling was then used to select the specific respondents for the study. The study used owners and top managers of the SMEs as respondents. The study was limited to the effects of Working Capital Management practices on the financial performance of Small and Medium Enterprises in Mandera County.

\section{Study Limitation}

There was limited literature from previous research on the topic and more so the objectives. The researcher relied on previous researches to form the basis of its literature.

The research was limited to registered and licensed SMEs. There was the need to also to include the unregistered as well as virtual SMEs to arrive at broader and comprehensive findings

\section{Theoretical Literature}

This section contains the review of theories relevant and which inform the theoretical background of the research subject matter. The theories reviewed are working capital management theory, finance theory and liquidity theory.

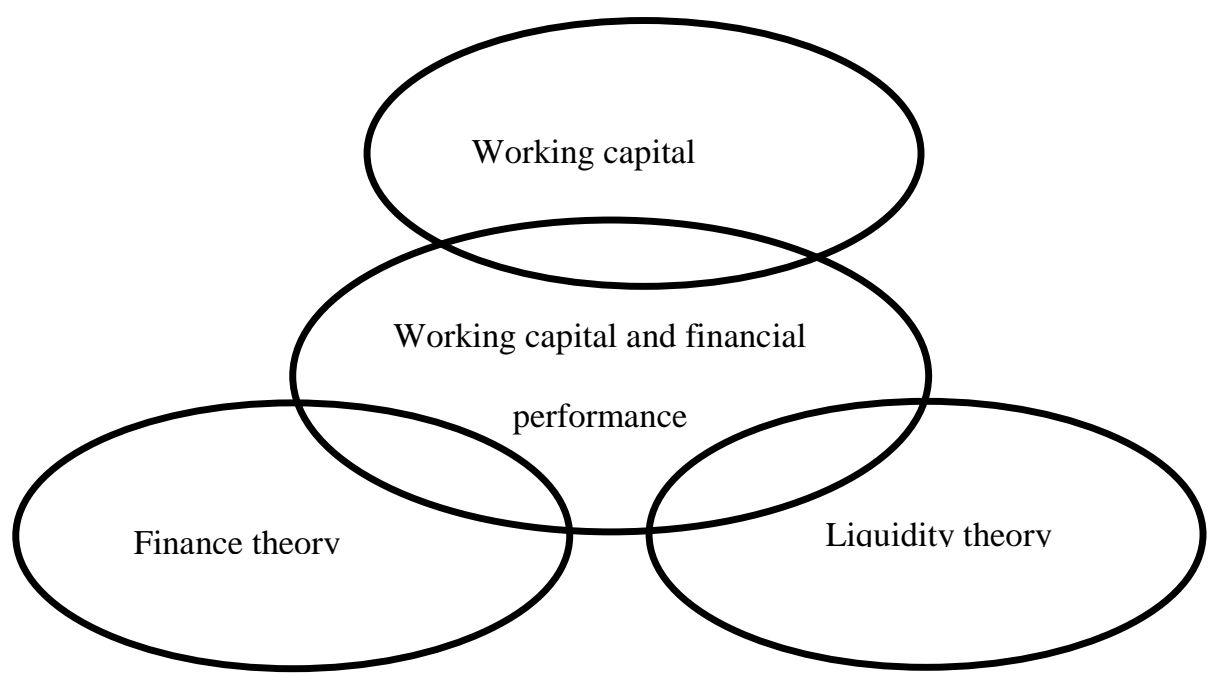

Figure 1: Theoretical framework.

\section{Working Capital Management Theory.}

Working capital management theory was advanced by (Smith, 2004).). This theory is guided by two methods static and dynamic. The static method is based on liquidity ratios. Commonly used current and quick ratios based on the data of balance sheet measures liquidity at some point in time. The dynamic method is related to the operations of the company (Brigham \&Ehrhardt, 2013).

There are two concepts of working capital namely quantitative and qualitative. According to the quantitative concept, the amount of working capital refers to the total of current assets. Current assets are considered to be gross working capital in this concept. The qualitative concept gives an idea regarding the source of financing capital. According to qualitative concept, the amount of working capital refers to "excess of current assets over current liabilities (Abuzayed, 2012). 
The excess of current assets over current liabilities is termed as; "Net working capital". In this concept; Net working capital represents the amount of current assets which would remain if all current liabilities were paid. Both the concepts of working capital have their points of importance (Appuhami, 2008). If the objectives are to measure the size and extent to which current assets are being used, the Gross concept is useful; whereas in evaluating the liquidity position of an undertaking; "Net concept" becomes pertinent and preferable (Hutchison, Farris \& Anders, 2007).

At one given time both the current assets and current liabilities exist in the business. The current assets and current liabilities are flowing around in a business like an electric current. However, working capital plays the same role in SMEs as the role of the heart in the human body. Working capital funds are generated and these funds are circulated in the SMEs. As and when this circulation stops, the SMEs become lifeless. It is because of this reason that the working capital is known as the circulating capital as it circulates in the SMEs just like blood in the human body (Smith \&Begemann, 1997)

\section{Finance Theory}

Megginson (1997) states that finance theory is under three main threads: capital budgeting, capital structure and working capital management. Capital budgeting and capital structure decisions are mostly related to financing and managing long-term investments while working capital management concerns financial decisions about working capital related to financing and managing short-term investments that undertake both current assets and current liabilities simultaneously.

The finance theory is relevant to the study because it explains the effects of having poor working capital management policies which can either lead to poor profits generation or shortages which affect the day to day operations of the SMEs. Less amount of working capital in SMEs will affect their day to day operations which may ultimately affect profits. If for instance there is less working capital to fix an urgent need, the same will lead to losses which would otherwise have been avoided if the SMEs had implemented proper working capital management policies in place.

\section{Liquidity Theory}

According to Jose (1996), Liquidity theory as a function of current assets and current liabilities is an important factor in determining working capital policies and indicates a firm's capability of generating cash in case of need. The theory states that current ratio, acid-test and cash ratios as traditional measures of liquidity are incompetent because these balance sheet based measures cannot provide detailed and accurate information about the effectiveness of working capital management. Formulas used for calculating these ratios consider both liquid and operating assets in common. Besides, mentioned traditional ratios are also not meaningful in terms of cash flows (Richards and Laughlin, 1980). The theory is relevant in understanding the process used by SMEs in maintaining cash inflow and outflow through profits generation, receivables and payments. This ensures that the SMEs are capable of generating cash in case of an emergency. Businesses with poor liquidity management measures are likely to experience inconveniences in their operations when an urgent need for cash arises.

\section{Conceptual Framework}

Independent Variable

Working capital management

\section{Dependent Variable \\ Performance of SMEs}

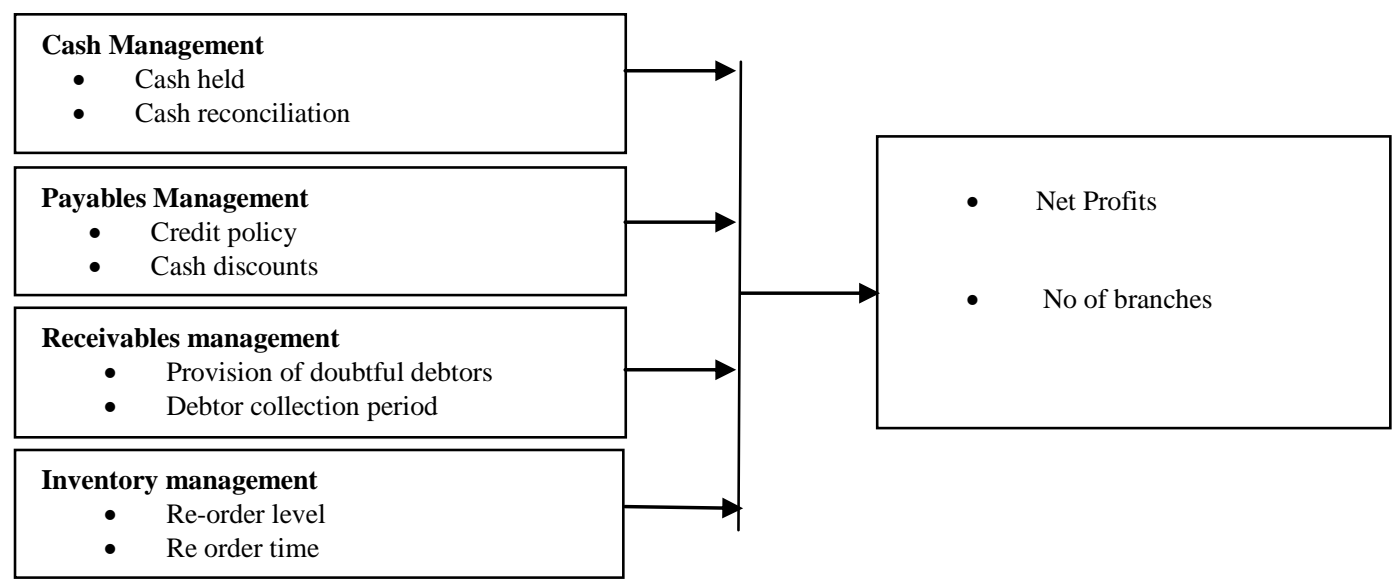

Figure 2: Conceptual Framework 
Figure 2 shows the relationship between the dependent and independent variables to be tested in the study. The dependent variable in this study will be the performance of SMEs. The independent variables to be included in the study are cash management practices, payables management practices, receivables management practices and inventory management practices.

\section{Research Design}

A descriptive survey design was employed in this study. Descriptive design was used because it focused on complex analysis to bring out the correlation of variables. Causal relationship seeks to establish how one variable affects changes in another. This was to focus on understanding, explaining, predicting and controlling relationships between variables.

\section{Target Population}

The target population for the research was comprised of established Juakali SME in Mandera County, Kenya. The total number of registered Juakali SMEs in Mandera was 600 as adopted from Mandera County as of 2017.

\section{Sampling procedures and techniques}

The researcher used simple random sampling to select the exact individuals to participate in the study. This technique offered each member of the study population an equal chance of inclusion in the sample.

\section{Sample Size}

This study adopted Yamane, Taro. (1967) sampling formula to compose the sample size. Hence the following formula was used;

$\mathrm{n}$ - The sample size

$$
n=\frac{N}{1+\left(N *(e)^{2}\right)}
$$

$\mathrm{N}$ - The population size

e - The acceptable sampling error

* 95\% confidence level and $p=0.05$ are assumed

$=\frac{600}{1+\left(600 *\left(0.05^{2}\right)\right)}$

$=240$

Using the above formula the sample was determined to be 240 which was considered to be good enough for the study.

\section{Data Collection Methods and Procedures}

Data collection refers to the process of gathering raw and unprocessed information that can be processed into meaningful information, following the scientific process of data analysis (Gall, Gall and Borg, 2007). Primary data were obtained from questionnaires. Closed-ended questions in form of a 5 point Likert scale was used to collect quantitative data. The questionnaires were self-administered with clarifications where necessary.

\section{Piloting of research instruments}

Before using a questionnaire to collect data it was pilot tested. The purpose of the pilot test was to refine the questionnaire so that respondents had no problems in answering the questions and there were no problems in recording the data. According to Baker, Veit and Powell (2001), the size of a sample was used for piloting testing varies depending on time, costs and practicality, but the same would tend to be 5-10 per cent of the main survey hence the current study will use 34 questionnaires in a pilot.

This represented $10 \%$ of the total sample of 344 respondents. Care was taken to exclude the respondents from the final survey. This enabled the researcher to fine-tune the questionnaire for objectivity and efficiency of the process. The questionnaire was estimated to take fifteen minutes to complete

\section{Testing for validity \& Reliability}

\section{Validity}

Validity refers to whether a questionnaire is measuring what it purports to measure (Newing, 2011). It describes validity as the degree of congruence between the explanations of the phenomena and the realities of the world. To ensure content validity, the questionnaire was subjected to thorough examination by two experts. They were asked to evaluate the statements in the questionnaire for relevance and whether they were meaningful, clear and 
loaded or offensive. Based on the evaluation, the instrument was adjusted appropriately before subjecting it to the final data collection exercise. Their review comments were used to ensure that content validity is enhanced.

\section{Reliability}

Reliability refers to the repeatability, stability or internal consistency of a questionnaire (Cooper and Schindler, 2006). The questionnaire responses of the pilot were inputted into a statistical package for social sciences (SPSS) and Cronbach's alpha coefficient generated to assess reliability. The closer Cronbach's alpha coefficient is to 1 , the higher the internal consistency reliability (Sekaran, 2006). A coefficient of 0.7 is recommended for a newly developed questionnaire.

\section{Data analysis techniques \& Procedures}

Data analysis is a practice in which raw data is ordered and organized so that useful information can be extracted from it (Gall et al, 2007). Descriptive statistics such as, mean and frequencies will be used to perform data analysis. The mean scores were used to rate the factors in order of their importance. SPSS was used to produce frequencies, descriptive and inferential statistics which were used to derive conclusions and generalizations regarding the population. The particular descriptive statistics were frequencies, mean scores and standard deviation. The particular inferential statistic was regression analysis. The analysis of variance (ANOVA) was checked to reveal the overall model significance. In particular, the calculated F statistic was compared with the tabulated F statistic.

A critical p-value of 0.05 was also used to determine whether the overall model was significant or not. The individual regression coefficients were checked to see whether the independent variables cash management practices, payables management practices, receivables management practices and inventory management practices significantly affect the performance of SMEs. A critical p-value of 0.05 will be also used to determine whether the individual variables are significant or not.

A multiple linear regression model was used to link the independent variables to the dependent variable as follows;

$Y=\beta_{0}+\beta_{1} X_{1}+\beta_{2} X_{2}+\beta_{3} X_{3}+\beta_{4} X_{4}+\mu$

Where;

$\mathrm{Y}=$ Performance of SMEs

$\mathrm{X}_{1}=$ Cash management practices

$\mathrm{X}_{2}=$ Payables management practices

$\mathrm{X}_{3}=$ Receivable management practices

$\mathrm{X}_{4}=$ Inventory management practices

In the model, $\beta_{0}=$ the constant term while the coefficient $\beta_{\mathrm{i}} 1=1 \ldots .4$ will be used to measure the sensitivity of the dependent variable $(\mathrm{Y})$ to a unit change in the predictor variables $\mathrm{X}_{1}, \mathrm{X}_{2}, \mathrm{X}_{3}$ and $\mathrm{X}_{4}, \mu$ is the error term which captures the unexplained variations in the model (Olusola et. al, 2013)

\section{Financial Performance}

The study assessed the performance of SMEs operating in Mandera County and findings presented in tables in frequencies and percentages as follows.

\section{Key financial performance indicator utilized by your SME}

Information was gathered from respondents on key financial performance indicator utilized by your SMEs in Mandera County and findings presented in table 1.

Table 1: Key financial performance indicator utilized by your SME

\begin{tabular}{|c|c|c|c|c|c|}
\hline & & Frequency & Percent & Valid Percent & Cumulative Percent \\
\hline \multirow{6}{*}{ Valid } & Customer satisfaction & 122 & 50.8 & 50.8 & 50.8 \\
\hline & Accounts payable turn over & 60 & 25.0 & 25.0 & 75.8 \\
\hline & Current ratio & 30 & 12.5 & 12.5 & 88.3 \\
\hline & Working capital & 1 & .4 & .4 & 88.8 \\
\hline & Operating cash flow & 27 & 11.3 & 11.3 & 100.0 \\
\hline & Total & 240 & 100.0 & 100.0 & \\
\hline
\end{tabular}

Findings presented in table 1 revealed that $50.8 \%$ mentioned that customer satisfaction was the key financial performance indicator utilized by SMEs, $25 \%$ mentioned accounts payable turnover, $12.5 \%$ mentioned current 
IRA-International Journal of Management \& Social Sciences

ratios, $0.4 \%$ mentioned working capital and $11.3 \%$ mentioned operating cash flow as the key financial performance indicator utilized by SMEs in the study area. These findings implied that amongst SMEs operating in the studied area, customer satisfaction was the key financial performance indicator utilized by most SMEs.

Individual rating of SME performance

The study gathered data on individual rating of SME performance and findings presented in table 2.

Table 2: Individual rating of SME performance

\begin{tabular}{rlrrrr}
\hline & Frequency & \multicolumn{1}{c}{ Percent } & Valid Percent & Cumulative Percent \\
\hline \multirow{6}{*}{ Valid } & 28 & 11.7 & 11.7 & 11.7 \\
& Very good & 93 & 38.8 & 38.8 & 50.4 \\
& Mood & 49 & 20.4 & 20.4 & 70.8 \\
& Poor & 42 & 17.5 & 17.5 & 88.3 \\
& Very poor & 28 & 11.7 & 11.7 & 100.0 \\
& Total & 240 & 100.0 & 100.0 & \\
\hline
\end{tabular}

The findings presented in table 2 showed that $11.7 \%$ of the SMEs were performing very good, $38.8 \%$ were performing good, $20.4 \%$ had moderate performance, $17.5 \%$ had poor performance while $11.7 \%$ were performing very poorly. These results implied that most SMEs had a good performance by the time of this study while very few performed very poorly.

SME Ratings of Performance

Further information was gathered through statements on the performance of SMEs in the studied area and results presented in table 3 .

Table 3: Ratings of SME Performance

\begin{tabular}{|c|c|c|c|c|c|c|c|c|c|c|}
\hline & \multicolumn{2}{|c|}{$\begin{array}{l}\text { Strongly } \\
\text { Disagree }\end{array}$} & \multicolumn{2}{|c|}{ Disagree } & \multicolumn{2}{|c|}{ Neutral } & \multicolumn{2}{|c|}{ Agree } & \multicolumn{2}{|c|}{$\begin{array}{l}\text { Strongly } \\
\text { Agree }\end{array}$} \\
\hline & f & $\%$ & f & $\%$ & f & $\%$ & f & $\%$ & f & $\%$ \\
\hline $\begin{array}{l}\text { My SME has adequate } \\
\text { working capital }\end{array}$ & 92 & 38.3 & 36 & 15.0 & 23 & 9.6 & 42 & 17.5 & 47 & 19.6 \\
\hline $\begin{array}{l}\text { My SME has adequate } \\
\text { operating cash flow }\end{array}$ & 76 & 31.7 & 68 & 28.3 & 15 & 6.3 & 29 & 12.1 & 52 & 21.7 \\
\hline $\begin{array}{l}\text { My SME has better capital } \\
\text { ration }\end{array}$ & 121 & 50.4 & 42 & 17.5 & 32 & 13.3 & 20 & 8.3 & 25 & 10.4 \\
\hline $\begin{array}{l}\text { My SME has manageable } \\
\text { debt to equity ratio }\end{array}$ & 22 & 9.2 & 41 & 17.1 & 30 & 12.5 & 79 & 32.9 & 68 & 28.3 \\
\hline $\begin{array}{l}\text { My SME achieves the } \\
\text { target revenue }\end{array}$ & 44 & 18.3 & 50 & 20.8 & 27 & 11.3 & 77 & 32.1 & 42 & 17.5 \\
\hline $\begin{array}{l}\text { My SME budget always } \\
\text { covers the required } \\
\text { expenses }\end{array}$ & 79 & 32.9 & 70 & 29.2 & 10 & 4.2 & 31 & 12.9 & 50 & 20.8 \\
\hline $\begin{array}{l}\text { My SME has an increasing } \\
\text { accounts payable turnover }\end{array}$ & 38 & 15.8 & 72 & 30.0 & 30 & 12.5 & 67 & 27.9 & 33 & 13.8 \\
\hline $\begin{array}{l}\text { Accounts receivable } \\
\text { turnovers are always almost } \\
\text { immediately in my SME }\end{array}$ & 50 & 20.8 & 69 & 28.8 & 39 & 16.3 & 51 & 21.3 & 31 & 12.9 \\
\hline $\begin{array}{l}\text { My SME has adequate } \\
\text { returns on equity }\end{array}$ & 104 & 43.3 & 64 & 26.7 & 34 & 14.2 & 25 & 10.4 & 13 & 5.4 \\
\hline $\begin{array}{l}\text { My SME adequately } \\
\text { utilizes its quick ratios }\end{array}$ & 31 & 12.9 & 38 & 15.8 & 34 & 14.2 & 81 & 33.8 & 56 & 23.3 \\
\hline $\begin{array}{l}\text { My customers are always } \\
\text { satisfied by My SMEs } \\
\text { performance }\end{array}$ & 14 & 5.8 & 20 & 8.3 & 48 & 20.0 & 106 & 44.2 & 52 & 21.7 \\
\hline
\end{tabular}

Findings presented in table 3 showed that $38.2 \%$ of the participants strongly disagreed that their SME had adequate working capital, 31.7\% strongly disagreed that their SME had adequate operating cash flow, 50.4\% strongly disagreed that their SME had a better capital ratio, 32.9\% agreed that their had manageable debt to 
equity ratio, 32.1\% agreed that their SME achieved the target revenue, 32.9\% strongly disagreed that SME budget always covered the required expenses, $30 \%$ disagreed that their SME had an increasing accounts payable turnover, 28.8\% disagreed that accounts receivable turnovers were always almost immediately in their SME, 43.3\% strongly disagreed that their SME had adequate returns on equity, 33.8\% agreed that their SME adequately utilized its quick ratios while $44.2 \%$ agreed that their customers were always satisfied by their SMEs performance. These study outcomes implied that in Mandera County SMEs performance was generally not good meaning that most were having poor growth and financial performance.

Effects of Cash Management Practice on Performance of SMEs in Mandera County

The first objective of the study assessed the effects of cash management practice on the performance of small and medium enterprises in Mandera County. Findings were presented in tables using frequencies and percentages as follows.

Main cash management practice employed by SME

Information was collected from research participants on the main cash management practices employed by SMEs and findings presented in table 4.

Table 4: Main cash management practice by SME

\begin{tabular}{llrrrr}
\hline & Frequency & Percent & Valid Percent & Cumulative Percent \\
\hline \multirow{4}{*}{ Valid } & Cash flow forecasting & 90 & 37.5 & 37.5 & 37.5 \\
& Understanding sales cycle & 73 & 30.4 & 30.4 & 67.9 \\
& Managing working capital & 77 & 32.1 & 32.1 & 100.0 \\
Total & 240 & 100.0 & 100.0 & \\
\hline
\end{tabular}

As findings in table 4 showed, $37.5 \%$ of SMEs utilized cash flow forecasting as the main cash management practice, $30.4 \%$ used sale cycle understanding while $32.1 \%$ managed working capital. From the results it was clear that the 3 cash management practices were equally being adopted by SMEs in the study are with cash flow forecasting being slightly being used more.

Effectiveness of cash management practices with regards to SME performance

In table 5, the researcher presents data gathered on the effectiveness of cash management practices with regards to SME performance.

Table 5: Effectiveness of cash management practices with regards to SME performance

\begin{tabular}{llrrrr}
\hline & Frequency & Percent & Valid Percent & Cumulative Percent \\
\hline \multirow{4}{*}{ Valid } & 39 & 16.3 & 16.3 & 16.3 \\
& Very effective & 46 & 19.2 & 19.2 & 35.4 \\
Effective & 62 & 25.8 & 25.8 & 61.3 \\
& Moderate & 46 & 19.2 & 19.2 & 80.4 \\
& Poor & 47 & 19.6 & 19.6 & 100.0 \\
& Very poor & 240 & 100.0 & 100.0 & \\
\hline
\end{tabular}

On the effectiveness of cash management practices, findings in table 5 established that $16.3 \%$ of the practices were very effective, $19.2 \%$ were effective, $25.8 \%$ were moderately effective, $19.2 \%$ were poor while $19.6 \%$ were very poor. The results implied that cash management practices were either moderately effective or poor concerning SME performance.

\section{Effects of Payables Management Practice on Performance of SMEs in Mandera County}

The second study objective addressed the effects of payables management practice on the performance of small and medium enterprises in Mandera County and the findings presented in tables in the form of frequencies and percentages.

Main accounts payable management practice adopted by this SME

The study collected data on the main accounts payable management practice adopted by this SME and outcomes presented in Table 6. 
IRA-International Journal of Management \& Social Sciences

\begin{tabular}{|c|c|c|c|c|}
\hline \multicolumn{5}{|c|}{ Table 6: Main accounts payable management practice adopted by this SME } \\
\hline & & Frequency & Per cent & $\begin{array}{c}\text { Valid } \\
\text { Percent }\end{array}$ \\
\hline \multirow{5}{*}{ Valid } & Purchasing in cash only & 78 & 32.5 & 32.5 \\
\hline & Seeking trade credit lines & 75 & 31.3 & 31.3 \\
\hline & Acquiring favourable terms of purchase & 53 & 22.1 & 22.1 \\
\hline & $\begin{array}{l}\text { Managing the flow and timing of purchases to efficiently } \\
\text { control the company's working capital }\end{array}$ & 34 & 14.2 & 14.2 \\
\hline & Total & 240 & 100.0 & 100.0 \\
\hline
\end{tabular}

The study results as presented in table 6 established that the main account payable management practice adopted by SMEs in Mandera County was purchased in cash only as $32.5 \%$ mentioned, $31.3 \%$ mentioned sought credit lines, $22.1 \%$ acquired favourable terms of purchase while $14.2 \%$ managed the flow and timing of purchases so as to efficiently control the company's working capital. Therefore, numerous accounts payable management practices were being employed by various SMEs in the studied area while purchasing in cash only was the main practice.

Effectiveness of accounts payable management practice in enhancing the performance of SMEs Respondents were asked how effective the accounts payable practices were in enhancing the performance of SMEs and the results presented in table 7.

Table 7: Effectiveness of accounts payable management practice in enhancing the performance of SMEs

\begin{tabular}{llrrrr}
\hline & Frequency & Percent & Valid Percent & Cumulative Percent \\
\hline \multirow{6}{*}{ Valid } & 52 & 21.7 & 21.7 & 21.7 \\
& Very effective & 58 & 24.2 & 24.2 & 45.8 \\
& Effective & 68 & 28.3 & 28.3 & 74.2 \\
& Moderate & 36 & 15.0 & 15.0 & 89.2 \\
& Poor & 26 & 10.8 & 10.8 & 100.0 \\
& Very poor & 240 & 100.0 & 100.0 &
\end{tabular}

Results, as presented in table 7 , revealed that $21.7 \%$ of the accounts payable management practices were very effective, $24.2 \%$ were effective, $28.3 \%$ were moderate, $15 \%$ were poor while $10.8 \%$ were very effective. The findings implied that the accounts payable management practices employed were either moderately effective or effective in enhancing the performance of SMEs in the studied area.

\section{Effects of accounts payable management practice on the performance of SMEs}

The study gathered information from managers and SME owners on the effects of accounts payable management practice on the performance of SMEs and findings presented in table 8.

Table 8: Effects of accounts payable management practice on the performance of SMEs

\begin{tabular}{|c|c|c|c|c|c|c|c|c|c|c|}
\hline & \multicolumn{2}{|c|}{$\begin{array}{l}\text { Strongly } \\
\text { Disagree }\end{array}$} & \multicolumn{2}{|c|}{ Disagree } & \multicolumn{2}{|c|}{ Neutral } & \multicolumn{2}{|c|}{ Agree } & \multicolumn{2}{|c|}{$\begin{array}{l}\text { Strongly } \\
\text { Agree }\end{array}$} \\
\hline & f & $\%$ & f & $\%$ & f & $\%$ & f & $\%$ & f & $\%$ \\
\hline $\begin{array}{l}\text { The time taken to pay Creditors } \\
\text { should be extended as long as } \\
\text { possible to maximize returns }\end{array}$ & 98 & 40.8 & 72 & 30.0 & 14 & 5.8 & 41 & 17.1 & 15 & 6.3 \\
\hline $\begin{array}{l}\text { Purchasing only in cash } \\
\text { improves SME performance }\end{array}$ & 0 & 0.0 & 22 & 9.2 & 18 & 7.5 & 73 & 30.4 & 127 & 52.9 \\
\hline $\begin{array}{l}\text { Negotiating for payments in } \\
\text { installments improves SME } \\
\text { performance }\end{array}$ & 21 & 8.8 & 35 & 14.6 & 25 & 10.4 & 87 & 36.3 & 72 & 30.0 \\
\hline $\begin{array}{l}\text { Longer credit periods with } \\
\text { suppliers improves SME } \\
\text { performance }\end{array}$ & 0 & 0.0 & 0 & 0.0 & 0 & 0.0 & 104 & 43.3 & 136 & 56.7 \\
\hline $\begin{array}{l}\text { Investing cash to pay in maturity } \\
\text { of grace period improves SME } \\
\text { performance }\end{array}$ & 0 & 0.0 & 0 & 0.0 & 0 & 0.0 & 90 & 37.5 & 150 & 62.5 \\
\hline
\end{tabular}


IRA-International Journal of Management \& Social Sciences

\begin{tabular}{|c|c|c|c|c|c|c|c|c|c|c|}
\hline $\begin{array}{l}\text { Cash purchases improves SME } \\
\text { performance }\end{array}$ & 0 & 0.0 & 0 & 0.0 & 0 & 0.0 & 142 & 59.2 & 98 & 40.8 \\
\hline $\begin{array}{l}\text { Credit purchases improves SME } \\
\text { performance }\end{array}$ & 62 & 25.8 & 51 & 21.3 & 15 & 6.3 & 68 & 28.3 & 44 & 18.3 \\
\hline $\begin{array}{l}\text { Taking advantage of discount } \\
\text { facilities by paying creditors } \\
\text { promptly improves SME } \\
\text { performance }\end{array}$ & 0 & 0.0 & 0 & 0.0 & 0 & 0.0 & 92 & 38.3 & 148 & 61.7 \\
\hline $\begin{array}{l}\text { Settling accounts payable on the } \\
\text { last day that the payment is due } \\
\text { improves SME performance }\end{array}$ & 0 & 0.0 & 0 & 0.0 & 0 & 0.0 & 95 & 39.6 & 145 & 60.4 \\
\hline $\begin{array}{l}\text { Use of computers to manage } \\
\text { accounts payable improves SME } \\
\text { performance }\end{array}$ & 0 & 0.0 & 0 & 0.0 & 0 & 0.0 & 130 & 54.2 & 110 & 45.8 \\
\hline
\end{tabular}

As the data presented in table 8 established, $40.8 \%$ of the participants agreed that the time taken to pay Creditors should be extended as long as possible in order to maximize returns, $52.9 \%$ strongly agreed that purchasing only in cash improves SME performance, 36.3\% agreed that negotiating for payments in instalments improves SME performance, $56.7 \%$ strongly agreed that longer credit periods with suppliers improves SME performance, $62.5 \%$ strongly agreed that investing cash to pay in the maturity of grace period improves SME performance, 59.2\% agreed that cash purchases improve SME performance, $28.3 \%$ agreed that credit purchases improve SME performance, $61.7 \%$ strongly agreed that taking advantage of discount facilities by paying creditors promptly improves SME performance, $60.4 \%$ strongly agreed that settling accounts payable on the last day that the payment is due improves SME performance and 54.2\% agreed that use of computers to manage accounts payable improves SME performance. The results implied that accounts payable management practices employed by SMEs in Mandera County improved the performance of SMEs in the region.

\section{Effect of Receivables Management Practice on Performance of SMEs in Mandera County}

The third objective of the study assessed the effect of receivables management practice on the performance of small and medium enterprises in Mandera County. Findings in frequencies and percentages are as presented in the tables below.

Accounts receivables management practices mainly employed by SME

Information was also gathered on accounts receivables management practices mainly employed by SMEs in Mandera County and results presented in table 9.

Table 9: Account receivables management practices mainly employed by SME

\begin{tabular}{llrrrr}
\hline & Frequency & Percent & Valid Percent & Cumulative Percent \\
\hline \multirow{4}{*}{ Valid } & 23 & 9.6 & 9.6 & 9.6 \\
& Accounts receivable analysis & 36 & 15.0 & 15.0 & 24.6 \\
Accounts receivable extension & 77 & 32.1 & 32.1 & 56.7 \\
Accounts receivable collection & 104 & 43.3 & 43.3 & 100.0 \\
Accounts receivable financing & 240 & 100.0 & 100.0 & \\
Total & & &
\end{tabular}

The study results ass in table 9 showed that $9.6 \%$ of SMEs in Mandera County employed accounts receivable analysis practice, $15 \%$ used accounts receivable extension, $32.1 \%$ used accounts receivable collection and $43.3 \%$ used accounts receivable financing. The results, therefore, implied that accounts receivable financing was the main accounts receivable management practice mainly employed by most SMEs in the studied region.

Effectiveness of account receivable management practices in enhancing performance SME

Additional data was gathered from respondents on the effectiveness of account receivable management practices in enhancing performance SME and the results presented in table 10. 
IRA-International Journal of Management \& Social Sciences

\begin{tabular}{|c|c|c|c|c|c|}
\hline & & Frequency & Percent & Valid Percent & Cumulative Percent \\
\hline \multirow{6}{*}{ Valid } & Very effective & 84 & 35.0 & 35.0 & 35.0 \\
\hline & Effective & 83 & 34.6 & 34.6 & 69.6 \\
\hline & Moderate & 27 & 11.3 & 11.3 & 80.8 \\
\hline & Poor & 32 & 13.3 & 13.3 & 94.2 \\
\hline & Very poor & 14 & 5.8 & 5.8 & 100.0 \\
\hline & Total & 240 & 100.0 & 100.0 & \\
\hline
\end{tabular}

As in table 10,35\% of the accounts receivable management practices employed by SMEs in the study area were very effective in enhancing SME performance, $34.6 \%$ were effective, $11.3 \%$ were moderately effective, $13.3 \%$ were poor while $5.8 \%$ were very poor in enhancing SME performance. Therefore, in Mandera County, accounts receivable management practices were generally effective in enhancing SME performance.

Effects of accounts receivable management practices on the performance of SMEs

Additional data was gathered from respondents on the effects of accounts receivable management practices on the performance of SMEs and findings presented in table 11.

Table 2: Effects of accounts receivable management practices on the performance of SMEs

\begin{tabular}{|c|c|c|c|c|c|c|c|c|c|c|}
\hline & \multicolumn{2}{|c|}{$\begin{array}{l}\text { Strongly } \\
\text { Disagree }\end{array}$} & \multicolumn{2}{|c|}{ Disagree } & \multicolumn{2}{|c|}{ Neutral } & \multicolumn{2}{|c|}{ Agree } & \multicolumn{2}{|c|}{$\begin{array}{l}\text { Strongly } \\
\text { Agree }\end{array}$} \\
\hline & $\mathbf{f}$ & $\%$ & $\mathbf{F}$ & $\%$ & f & $\%$ & $\mathbf{f}$ & $\%$ & $\mathbf{F}$ & $\%$ \\
\hline $\begin{array}{l}\text { The business always insist on } \\
\text { cash payment from customers to } \\
\text { avoid credits improves SME } \\
\text { performance }\end{array}$ & 0 & 0.0 & 0 & 0.0 & 0 & 0.0 & 84 & 35.0 & 156 & 65.0 \\
\hline $\begin{array}{l}\text { The length of accounts } \\
\text { receivables period has an impact } \\
\text { on profitability of the SME }\end{array}$ & 0 & 0.0 & 0 & 0.0 & 0 & 0.0 & 101 & 42.1 & 139 & 57.9 \\
\hline $\begin{array}{l}\text { Shorter accounts receivable } \\
\text { periods improves SME } \\
\text { performance }\end{array}$ & 0 & 0.0 & 0 & 0.0 & 0 & 0.0 & 98 & 40.8 & 142 & 59.2 \\
\hline $\begin{array}{l}\text { SMEs should have good debt } \\
\text { management policies to ensure } \\
\text { that bad debts are provided for }\end{array}$ & 0 & 0.0 & 0 & 0.0 & 0 & 0.0 & 84 & 35.0 & 156 & 65.0 \\
\hline $\begin{array}{l}\text { Debtors collection period should } \\
\text { be reduced granting a short } \\
\text { period as this enhances SME } \\
\text { financial growth }\end{array}$ & 0 & 0.0 & 0 & 0.0 & 0 & 0.0 & 106 & 44.2 & 134 & 55.8 \\
\hline $\begin{array}{l}\text { Analyzing customers' paying } \\
\text { history to determine capacity to } \\
\text { pay enhances SME financial } \\
\text { growth }\end{array}$ & 0 & 0.0 & 0 & 0.0 & 0 & 0.0 & 90 & 37.5 & 150 & 62.5 \\
\hline $\begin{array}{l}\text { Contacting third parties for } \\
\text { references (credit worthiness of } \\
\text { customers) enhances SME } \\
\text { financial growth }\end{array}$ & 14 & 5.8 & 13 & 5.4 & 0 & 0.0 & 84 & 35.0 & 129 & 53.8 \\
\hline $\begin{array}{l}\text { Scrutinizing customers' account } \\
\text { to determine his capital base } \\
\text { enhances SME financial growth }\end{array}$ & 0 & 0.0 & 0 & 0.0 & 12 & 5.0 & 97 & 40.4 & 131 & 54.6 \\
\hline $\begin{array}{l}\text { Making a follow up on collateral } \\
\text { issued enhances SME financial } \\
\text { growth }\end{array}$ & 0 & 0.0 & 0 & 0.0 & 24 & 10.0 & 84 & 35.0 & 132 & 55.0 \\
\hline $\begin{array}{l}\text { Utilization of formalized credit } \\
\text { processes(documentation of } \\
\text { agreement) enhances SME } \\
\text { financial growth }\end{array}$ & 0 & 0.0 & 0 & 0.0 & 0 & 0.0 & 128 & 53.3 & 112 & 46.7 \\
\hline $\begin{array}{l}\text { Use of third party provided } \\
\text { intelligence enhances SME }\end{array}$ & 0 & 0.0 & 0 & 0.0 & 0 & 0.0 & 84 & 35.0 & 156 & 65.0 \\
\hline
\end{tabular}


IRA-International Journal of Management \& Social Sciences

\begin{tabular}{|c|c|c|c|c|c|c|c|c|c|c|}
\hline \multicolumn{11}{|l|}{ financial growth } \\
\hline $\begin{array}{l}\text { Contacting overdue accounts } \\
\text { holders enhances SME financial } \\
\text { growth }\end{array}$ & 0 & 0.0 & 0 & 0.0 & 0 & 0.0 & 58 & 24.2 & 182 & 75.8 \\
\hline $\begin{array}{l}\text { Reviewing credit collection } \\
\text { timelines enhances SME } \\
\text { financial growth }\end{array}$ & 0 & 0.0 & 0 & 0.0 & 0 & 0.0 & 84 & 35.0 & 156 & 65.0 \\
\hline $\begin{array}{l}\text { Calling customers prior to due } \\
\text { date enhances SME financial } \\
\text { growth }\end{array}$ & 24 & 10.0 & 0 & 0.0 & 9 & 3.8 & 84 & 35.0 & 123 & 51.3 \\
\hline $\begin{array}{l}\text { Utilization of average credit } \\
\text { collection period technique } \\
\text { enhances SME financial growth }\end{array}$ & 0 & 0.0 & 0 & 0.0 & 0 & 0.0 & 52 & 21.7 & 188 & 78.3 \\
\hline
\end{tabular}

The study outcomes in table 11 revealed that $65 \%$ of participants strongly agreed that the business always insist on cash payment from customers to avoid credits improves SME performance, $57.9 \%$ strongly agreed that the length of accounts receivables period has an impact on profitability of the SME, $59.2 \%$ strongly agreed that shorter accounts receivable periods improves SME performance, 65\% strongly agreed that SMEs should have good debt management policies to ensure that bad debts are provided for, $55.8 \%$ strongly agreed that debtors collection period should be reduced granting a short period as this enhances SME financial growth, 62.5\% strongly agreed that analyzing customers' paying history to determine capacity to pay enhances SME financial growth, 53.8\% strongly agreed that contacting third parties for references (credit worthiness of customers) enhances SME financial growth, 54.6\% strongly agreed that that scrutinizing customers' account to determine his capital base enhances SME financial growth, 55\% strongly agreed that making a follow up on collateral issued enhances SME financial growth, 53.3\% agreed that utilization of formalized credit processes(documentation of agreement) enhances SME financial growth, 65\% strongly agreed that use of third party provided intelligence enhances SME financial growth, $75.8 \%$ strongly agreed that contacting overdue accounts holders enhances SME financial growth, 51.3\% strongly agreed that calling customers prior to due date enhances SME financial growth while $78.2 \%$ strongly agreed that utilization of average credit collection period technique enhances SME financial growth. This implied that accounts receivable management practices employed by SMEs affected SME performance greatly in Mandera County Kenya.

\section{Effect of Inventory Management Practice on Performance of SMEs in Mandera County}

The last objective of the study assessed the effect of inventory management practice on the performance of small and medium enterprises in Mandera County. Findings were presented in tables using frequencies and percentages as follows.

Inventory management practice employed regularly by SME

Information was gathered from respondents on inventory management practice employed regularly by SMEs and results presented in table 12 .

Table 3: Inventory management practice employed regularly by SME

\begin{tabular}{|c|c|c|c|c|c|}
\hline & & Frequency & Per cent & $\begin{array}{c}\text { Valid } \\
\text { Percent }\end{array}$ & $\begin{array}{c}\text { Cumulative } \\
\text { Percent }\end{array}$ \\
\hline \multirow{6}{*}{ Valid } & First in first out for perishable stock & 68 & 28.3 & 28.3 & 28.3 \\
\hline & $\begin{array}{l}\text { Last in first out for heavy } \\
\text { materials/goods }\end{array}$ & 36 & 15.0 & 15.0 & 43.3 \\
\hline & Minimal stock level & 42 & 17.5 & 17.5 & 60.8 \\
\hline & $\mathrm{ABC}$ analysis & 49 & 20.4 & 20.4 & 81.3 \\
\hline & Just in time & 45 & 18.8 & 18.8 & 100.0 \\
\hline & Total & 240 & 100.0 & 100.0 & \\
\hline
\end{tabular}

In table 12 , the results established that $28.3 \%$ of SMEs employed first in first out for perishable stocks inventory management practice regularly, $15 \%$ employed last in first out for heavy goods, $17.5 \%$ used minimal stock level practice, $20.4 \%$ used $\mathrm{ABC}$ analysis while $18.8 \%$ used just in time inventory management practice. This implied that various inventory management practices were being employed by SMEs with the most common one being first in first out for perishable stocks. 
IRA-International Journal of Management \& Social Sciences

Effects of inventory management practice employed on the performance of SME

The study lastly gathered data on the effects of inventory management practice employed on the performance of SME and findings presented in table 13.

Table 13: Effects of inventory management practice employed on the performance of SME

\begin{tabular}{|c|c|c|c|c|c|c|c|c|c|c|}
\hline & \multicolumn{2}{|c|}{$\begin{array}{l}\text { Strongly } \\
\text { agree }\end{array}$} & \multicolumn{2}{|c|}{ Agree } & \multicolumn{2}{|c|}{ Neutral } & \multicolumn{2}{|c|}{ Disagree } & \multicolumn{2}{|c|}{$\begin{array}{l}\text { Strongly } \\
\text { disagree }\end{array}$} \\
\hline & f & $\%$ & $\mathbf{F}$ & $\%$ & f & $\%$ & f & $\%$ & f & $\%$ \\
\hline $\begin{array}{l}\text { The length which stocks are } \\
\text { held influences profitability } \\
\text { of the business }\end{array}$ & 0 & 0.0 & 0 & 0.0 & 0 & 0.0 & 33 & 13.8 & 207 & 86.3 \\
\hline $\begin{array}{l}\text { The SME should have a set } \\
\text { economic order quantity to } \\
\text { ensure that stocks are } \\
\text { maintained }\end{array}$ & 0 & 0.0 & 0 & 0.0 & 0 & 0.0 & 84 & 35.0 & 156 & 65.0 \\
\hline $\begin{array}{l}\text { SMEs should set aside funds } \\
\text { to be used for re ordering }\end{array}$ & 0 & 0.0 & 0 & 0.0 & 0 & 0.0 & 10 & 4.2 & 230 & 95.8 \\
\hline $\begin{array}{l}\text { A longer stock holding period } \\
\text { has a negative effect on } \\
\text { profitability of the SME }\end{array}$ & 0 & 0.0 & 0 & 0.0 & 0 & 0.0 & 0 & 0.0 & 240 & 100.0 \\
\hline $\begin{array}{l}\text { The business has set } \\
\text { inventory management } \\
\text { policies that help prevent } \\
\text { stock outs and surpluses }\end{array}$ & 83 & 34.6 & 104 & 43.3 & 23 & 9.6 & 18 & 7.5 & 12 & 5.0 \\
\hline $\begin{array}{l}\text { Using first in first out for } \\
\text { perishable stock process of } \\
\text { sale enhances SMEs financial } \\
\text { performance }\end{array}$ & 0 & 0.0 & 0 & 0.0 & 0 & 0.0 & 19 & 7.9 & 221 & 92.1 \\
\hline $\begin{array}{l}\text { Utilization of last in first out } \\
\text { for heavy products during } \\
\text { sales enhances SMEs } \\
\text { financial performance }\end{array}$ & 8 & 3.3 & 11 & 4.6 & 14 & 5.8 & 18 & 7.5 & 189 & 78.8 \\
\hline $\begin{array}{l}\text { Keeping minimal stock levels } \\
\text { enhances SMEs financial } \\
\text { performance }\end{array}$ & 0 & 0.0 & 0 & 0.0 & 0 & 0.0 & 33 & 13.8 & 207 & 86.3 \\
\hline $\begin{array}{l}\text { ABC analysis enhances SMEs } \\
\text { financial performance }\end{array}$ & 0 & 0.0 & 0 & 0.0 & 30 & 12.5 & 10 & 4.2 & 200 & 83.3 \\
\hline $\begin{array}{l}\text { Utilizing just in time practices } \\
\text { by only buying what is } \\
\text { needed from a vendor when } \\
\text { one gets a customer sales } \\
\text { order enhances SMEs } \\
\text { financial performance }\end{array}$ & 0 & 0.0 & 0 & 0.0 & 0 & 0.0 & 69 & 28.8 & 171 & 71.3 \\
\hline
\end{tabular}

Data presented in table 13 revealed that $86.3 \%$ of study participants strongly agreed that the length which stocks are held influences profitability of the business, $65 \%$ strongly agreed that the SME should have a set economic order quantity to ensure that stocks are maintained, $95.8 \%$ strongly agreed that SMEs should set aside funds to be used for reordering, $100 \%$ strongly agreed that a longer stock holding period has a negative effect on profitability of the SME, $43.3 \%$ disagreed that the business has set inventory management policies that help prevent stock-outs and surpluses, $92.1 \%$ strongly agreed that using first in first out for perishable stock process of sale enhances SMEs financial performance, $78.8 \%$ strongly agreed that utilization of last in first out for heavy products during sales enhances SMEs financial performance, $86.3 \%$ strongly agreed that keeping minimal stock levels enhances SMEs financial performance, 83.3\% ABC analysis enhances SMEs financial performance while $71.3 \%$ strongly agreed that utilizing just in time practices by only buying what is needed from a vendor when one get a customer sales order enhances SMEs financial performance. The findings, therefore, implied that inventory management practices employed by SMEs positively influenced SME performance in Mandera County Kenya. 
IRA-International Journal of Management \& Social Sciences

Analysis of Variance of the Influence of Cash Management Practices on Performance of SMEs in Mandera County Kenya

Analysis of variance was used to test the relationship between cash management practices and performance of SMEs in Mandera County Kenya at 95\% confidence level and findings presented in table 14.

Table 14: Analysis of Variance of the Influence of Cash Management Practices on Performance of SMEs in Mandera County Kenya

\begin{tabular}{|c|c|c|c|c|c|c|}
\hline & & $\begin{array}{l}\text { Sum of } \\
\text { Squares }\end{array}$ & df & $\begin{array}{l}\text { Mean } \\
\text { Square }\end{array}$ & $\mathbf{F}$ & Sig. \\
\hline \multirow{5}{*}{ Cash management practice } & Between & 223.178 & 4 & 55.794 & 147.790 & .000 \\
\hline & Groups & & & & & \\
\hline & Within & 88.718 & 235 & .378 & & \\
\hline & Groups & & & & & \\
\hline & Total & 311.896 & 239 & & & \\
\hline \multirow{5}{*}{ accounts payable management practice } & Between & 253.669 & 4 & 63.417 & 161.876 & .000 \\
\hline & Groups & & & & & \\
\hline & Within & 92.064 & 235 & .392 & & \\
\hline & Groups & & & & & \\
\hline & Total & 345.733 & 239 & & & \\
\hline \multirow{4}{*}{$\begin{array}{l}\text { Account receivables management } \\
\text { practices }\end{array}$} & Between & 64.940 & 4 & 16.235 & 89.651 & .000 \\
\hline & Groups & & & & & \\
\hline & Within & 42.556 & 235 & .181 & & \\
\hline & Total & 107.496 & 239 & & & \\
\hline \multirow{5}{*}{ Inventory management practice } & Between & 233.187 & 4 & 58.297 & 163.100 & .000 \\
\hline & Groups & & & & & \\
\hline & Within & 83.996 & 235 & .357 & & \\
\hline & Groups & & & & & \\
\hline & Total & 317.183 & 239 & & & \\
\hline
\end{tabular}

The analysis of variance findings on the influence of cash management practices on the performance of SMEs in Mandera County Kenya established that there was a strong and significant relationship between all the studied independent variables of cash management practices, accounts payable management practices, accounts receivable management practices and inventory management practices and SMEs performance in Mandera County as all the $\mathrm{p}$-value of $\mathrm{p}=0.000$ was greater than $\mathrm{p}=0.05$. Hence, cash management practices had a statistically significant relationship with the studied SMEs performance.

\section{Discussion of Findings}

Effects of Cash Management Practice on Performance of SMEs in Mandera County

The study findings showed that cash management practice employed by SMEs in Mandera County were cash flow forecasting, sale cycle understanding and management of working capital. These cash management practices were either moderately effective or poor concerning SME performance. Further, cash management practices used by SME operators generally improved SME performance in Mandera County Kenya.

\section{Effects of Payables Management Practice on Performance of SMEs in Mandera County}

The results also showed that account payable management practice adopted by SMEs in Mandera County was purchased in cash only, seeking credit lines, acquiring favourable terms of purchase and managing the flow and timing of purchases so as to efficiently control the company's working capital. Accounts payable management practices were both moderately effective and effective in enhancing the performance of SMEs in the studied area. The accounts payable management practices employed by SMEs in Mandera County, therefore, improved the performance of SMEs in the region.

\section{Effect of Receivables Management Practice on Performance of SMEs in Mandera County}

Findings of the study showed that accounts receivable practices employed by SMEs in Mandera County were accounts receivable analysis practice, accounts receivable extension, accounts receivable collection and accounts receivable financing. However, accounts receivable financing was the main accounts receivable management practice mainly employed by most SMEs in the studied region. Further, in Mandera County, accounts receivable management practices were generally effective in enhancing SME performance. 


\section{Effect of Inventory Management Practice on Performance of SMEs in Mandera County}

According to the findings, the inventory management practice employed regularly by SMEs in Mandera County was first in first out for perishable stocks inventory management, last in first out for heavy goods, minimal stock level practice, $\mathrm{ABC}$ analysis and just in time inventory management practice. Therefore, inventory management practices employed by SMEs positively influenced SME performance in Mandera County Kenya.

\section{Summary}

\section{Effects of Cash Management Practice on Performance of SMEs in Mandera County}

Concerning the effects of cash management practice on the performance of small and medium enterprises in Mandera County, cash management practice employed by SMEs in Mandera County were found to be cash flow forecasting, sale cycle understanding and managed working capital. These cash management practices were either moderately effective or poor with respect to SME performance. Further, cash management practices used by SME operators generally improved SME performance in Mandera County Kenya.

\section{Effects of Payables Management Practice on Performance of SMEs in Mandera County}

The second study objective addressed the effects of payables management practice on the performance of small and medium enterprises in Mandera County. From the results, account payable management practice adopted by SMEs in Mandera County was purchased in cash only, seeking credit lines, acquiring favourable terms of purchase and managing the flow and timing of purchases so as to efficiently control the company's working capital. Accounts payable management practices were both moderately effective and effective in enhancing the performance of SMEs in the studied area. The accounts payable management practices employed by SMEs in Mandera County, therefore, improved the performance of SMEs in the region.

\section{Effect of Receivables Management Practice on Performance of SMEs in Mandera County}

The third objective of the study assessed the effect of receivables management practice on the performance of small and medium enterprises in Mandera County. Findings of the study established that accounts receivable practices employed by SMEs in Mandera County were accounts receivable analysis practice, accounts receivable extension, accounts receivable collection and accounts receivable financing. However, accounts receivable financing was the main accounts receivable management practice mainly employed by most SMEs in the studied region. Further, in Mandera County, accounts receivable management practices were generally effective in enhancing SME performance.

\section{Effect of Inventory Management Practice on Performance of SMEs in Mandera County}

The last objective of the study assessed the effect of inventory management practice on the performance of small and medium enterprises in Mandera County. According to the findings, the inventory management practice employed regularly by SMEs in Mandera County was first in first out for perishable stocks inventory management, last in first out for heavy goods, minimal stock level practice, $\mathrm{ABC}$ analysis and just in time inventory management practice. Therefore, inventory management practices employed by SMEs positively influenced SME performance in Mandera County Kenya.

\section{Conclusions}

With respect to the first objective, the study concludes that cash management practices employed by SMEs affected their performance negatively in Mandera County. For the second objective, the study concludes that accounts payable management practices employed by SMEs in Mandera County improved the performance of SMEs. Concerning the third objective, the study concludes that accounts receivable management practices were generally effective in enhancing SME performance. In the last objective, the study concludes that inventory management practices employed by SMEs positively influenced SME performance in the studied area.

\section{Recommendations of the Study}

The study recommends that;

$>$ There is a need for small and medium scale enterprises to employ effective cash management practices in order to improve SMEs performance

$>$ SMEs must select from the existing cash payable practices the most effective ones in order to improve the performance of their ventures

$>$ Only accounts receivable management practice with the highest effect on performance ought to be adopted by SMEs in order to enhance performance

$>$ SMEs choose suitable inventory management practices to positively influence their performance based on the type of goods that they engage in 


\section{References}

[1]. Abuzayed, B. (2012). Working Capital Management And Firms' Performance In Emerging Markets: The Case Of Jordan. International Journal of Managerial Finance, 8(2), 155-179. DOI: https://doi.org/10.1108/17439131211216620

[2]. Anders, S.B., M.T. Farris, P.D. Hutchison. (2007). Cash to Cash Analysis and Management. The CPA Journal August, 42-48.

[3]. Appuhami, B. A. R. (2008). The Impact of Firms' Capital Expenditure on Working Capital Management: An Empirical Study Across Industries in Thailand. International Management Review, 4(1), 1-10.

[4]. Atiase, V. Mahmood, S. Wang, Y. \& Botchie, D. (2017). Developing entrepreneurship in Africa: investigating critical resource challenges. Journal of Small Business and Enterprise Development, 25(4), 644-666. DOI: https://doi.org/10.1108/JSBED-03-2017-0084

[5]. Baker, H. K., Veit, E.T., \& Powell, G. E. (2001). Factors influencing dividend policy decisions of Nasdaq firms. The Financial Review, 36(3), pp.19-37. DOI: https://doi.org/10.1111/j.1540-6288.2001.tb00018.x

[6]. Copley, A. (2017). Figures of the Week: entrepreneurship and industrialization in Africa. Retrieved March 19, 2018, from https://www.brookings.edu/blog/africa-in-focus/2017/12/01/figures-of-the-week-implementingafricanindustrialization-strategies/

[7]. Fahmi, I. (2014). Analisis Kinerja Keuangan: Panduan Bagi Akademisi, Manajer, dan Investor Untuk Menilaidan Menganalisis Bisnis. Bandung: Alfabeta.

[8]. Holmes, R., McCord, A., Hagen Zanker, J., Bergh, G., \& Zanker, F. (2013). What is the evidence on the impact of employment creation on stability and poverty reduction in fragile states? A Systematic Review.Overseas Development Institute. Retrieved March 19, 2018, from https://www.odi.org/sites/odi.org.uk/files/odiassets/publicationsfiles/8386.pdf

[9]. Horne, J. \& Wachowitz, J. (2000). Fundamentals of Financial Management.10th Edn. Prentice-Hall International, Inc., New Jersey, ISBN: 0-13-8898820

[10].Jose, M.L., Lancaster, C. \& Stevens, J. L. (1996).Corporate returns and cash-conversion cycles.J. Econ. Finance, 20: 33-46. DOI: https://doi.org/10.1007/BF02920497

[11].Kargar, J. \& Bluementhal, R.A. (1994). Leverage impact on working capital in small business. TMA J., 14: 46-53.

[12].Kasmir.(2016). Analisis Laporan Keuangan, Edisi 1, Cetakan 9. Jakarta: PT. Raja Grafindo Persada.

[13].Katua, T. (2014).The role of SMEs in employment creation and economic growth in selected countries. International Journal of Education and Research, 2(12), 461-472

[14].Kenya National Bureau of Statistics, (2007), Micro and Small Enterprise Survey, 2007, Nairobi, Kenya.

[15].Kerr, A., Wittenburg, M., \& Arrow, J. (2013). Who creates jobs, who destroys jobs? Small firms, large firms and labour market rigidity. Retrieved March 19, 2018, from www.econ3x3.org

[16].Khan, M.Y. (2005).Basic financial management, 2nd edition, Tata McGraw-Hill Education, New Delhi.

[17].Kombo, D.K. \& Tromp, L.A. (2009). Proposal and Thesis Writing: An Introduction. Nairobi: Paulines Publications Africa

[18].Koontz, H. \& Donnell, C. (2003).Introduction to Management. McGraw-Hill Inc., New York.

[19].Kothari, C. (2004). Research Methodology: Methods \& Techniques. $2^{\text {nd }}$ Ed. New Delhi, India: New age International Publishers

[20].Lazaridis, I. \& Dimitrios, T. (2005).The relationship between working capital management and profitability of listed companies in the Athens Stock Exchange. Retrieved from http://ssrn.com/ in 2015.

[21].Luqman, O. S. (2014). A Comparative Analysis on Working Capital Management of Brewery Companies in Nigeria.Available at SSRN.

[22].M Bowen, M Morara, M Mureithi - KCA journal of business, 2009

[23].M. J. Brennan, V. Maksimovic and J. Zechner, "Vendor Financing," Journal of Finance, Vol. 43, No. 5, 2003, pp. 1127-1141. DOI: https://doi.org/10.1111/j.1540-6261.1988.tb03960.x

[24].Makori, D. M. \& Jagongo, A. (2013). Working Capital Management and Firm Profitability: Empirical Evidence from Manufacturing and Construction Firms Listed on Nairobi Securities Exchange, Kenya. International Journal of Accounting and Taxation, 1(1), 1-14.

[25].Matoha, Dumea (2007). Research on Working Capital Management of Publishing Companies, Unpublished Research Work, University of Dar es Salaam, Tanzania.

[26].Meghana, A., Demirguc-Kunt, A., \& Maksimovic, V. (2014). Who creates jobs in developing countries? Small Business Economics, 43, 75-99. DOI: https://doi.org/10.1007/s11187-014-9549-5

[27].Megginson, W. L. (1997). Corporate finance theory.Addison-Wesley.

[28].Memba, Gakure, and Karanja (2012) examined the impact of venture capital on the growth of SMEs in Kenya

[29]. Mukhopadhyay, D. (2004). Working Capital Management in Heavy Engineering Firms-A Case Study.

[30].Murphy, B, 1979, Assessing the value of financial control techniques to the smaller business, Certified Accountant, 71(2), p. 93-5,148

[31].Mwaura, J. (2013). The effect of financial planning on the financial performance of automobile firms in Kenya. http://erepository.uonbi.ac.ke/bitstream/handle/11295/58867.pdfNewing, H. (2010). Conducting research in conservation: social science methods and practice. Routledge.

[32].Nobanee, M. \&AlHajjar, R. (2009b).A note on working capital management and corporate profitability of Japanese firms. DOI: https://doi.org/10.2139/ssrn.1433243

[33].Nyamao, N. R., Patrick, O., Martin, L., Odondo, A. J., \&Simeyo, O. (2012). Effect of working capital management practices on financial performance: A study of small scale enterprises in Kisii South District, Kenya. African Journal of Business Management, 6(18), 5807-5817. DOI: https://doi.org/10.5897/AJBM11.1418 
[34].Nyambwaga, R. N., Ojera, P., Lumumba, M., Odondo, A., \&Otieno, S. (2012). Effect of working capital management practices on financial performance: A study of small scale enterprises in Kisii South District, Kenya. African Journal of Business Management, 6, 5807-5817. DOI: https://doi.org/10.5897/AJBM11.1418

[35]. Olowe, A. (2008). Financial management: Concepts, financial system and business finance. Lagos: Brierly Jones Nigeria Limited. Ross, S. A. Westerfield, R. W. and Jaffe, J, 1999, Corporate Finance, 5 edition, Irwin and McRaw-Hill, Boston

[36].Olusola, A.J., Olugbenga, O.M., Adeoluwa, Z.O., \& Oluwagbemiga, O.E. (2013). Accounting Information on Investment in Nigerian Poultry Agricultural Sector.Research Journal of Finance and Accounting, Vol. 4(19).

[37]. Overton, R. (2007).An empirical study on financial planning theory and practice, American Economic Review 73:89-95.

[38].Padachi, K. (2006). Trends in Working Capital Management and its Impact on Firms' Performance: An Analysis of Mauritian Small Manufacturing Firms. International Review of Business Research Papers, 2, 45 -58.

[39].Pinches, G.E. (1992).Essentials of Financial Management. 4th Edn., HarperCollins Publishers, New York, ISBN: 0-06-500450-7.

[40].Pindado, M. C. (2004). Cash Management Corporate Strategies, 5th ed. Wiley Inter-Science, New York.

[41].Raheman, A. \& Nasr, M. (2007). Working Capital Management and Profitability: Case of Pakistani Firms, International Review of Business Research Papers, Vol.3, No 1, PP279- 300

[42].Richards, V.D. \& Laughlin, E.J. (1980). A cash conversion cycle approach to liquidity analysis. Finance Management Pap,9: 32-38. DOI: https://doi.org/10.2307/3665310

[43].Ross, S. A., Westerfield, R. W., \& Jordan, B. D. (2008).Fundamentals of Corporate Finance. New York: McGrawHill Irwin Publications.

[44].Safavian, M. S., Wimpey, J. S., \& Amin, M. (2016). Informal enterprises in Kenya (English). Washington, D.C. World Bank Group. Retrieved March 18, 2018, from http://documents.worldbank.org/curated/en/262361468914023771/Informal-enterprises-in-Kenya

[45].Sallah, A. (2016). Re-reading the narrative of the informal economy in the context of economic development in sub-Saharan Africa. International Journal of Social Economics, 43(10), 1063- 1078. https://doi.org/10.1108/ IJSE04-2015-0091. DOI: https://doi.org/10.1108/IJSE-04-2015-0091

[46]. Samet E. \&Nazan Ş. (2018). The Effect of Working Capital Management on Profitability in Emerging Countries: Evidence from Turkey. https://www.intechopen.com/books/financial-management-from-an-emerging-marketperspective/the-effect-of-working-capital-management-on-profitability-in-emerging-countries-evidence-fromturkey

[47].Saunders M., Lewis P., \& Thornhill, A. (2012). Research methods for business students. $6^{\text {th }}$ Ed. Pearson professional Limited.

[48].Sekaran, U. (2006). Research Methods for Business: A Skill Building Approach. $4^{\text {th }}$ Ed. New Delhi, India: John Willey and Sons, Ltd.

[49].Shin, H. H., \&Stulz, R. M. (2000). Firm value, risk, and growth opportunities (No. w 7808). National bureau of economic research. DOI: https://doi.org/10.3386/w7808

[50].Simidi P. \& Duncan, O. (2017). Effects of working capital management on financial performance of energy and petroleum companies listed at Nairobi Securities Exchange. African Development Finance Journal http://journals.uonbi.ac.ke/index.php/adfj October Vol1 No.1, 2017 PP 61-79

[51].SME Solutions Centre, (2007). SSC Services-Kenya retrieved from (www.ssc.co.ke/services)

[52].Smith, M.B. and E. Begemann. 1997. Measuring Association between Working Capital and Return on Investment. South Africa Journal of Business Management, 28(1). DOI: https://doi.org/10.4102/sajbm.v28i1.783

[53].Sushma, V., \& Bhupesh, S. (2007).Effect of Working Capital Management Policies on Corporate Performance an Empirical Study.Sage journals, 8-267. DOI: https://doi.org/10.1177/097215090700800206

[54].Tully, S. (1994). Raiding a company's hidden cash. Fortune, 130(4), 82-87.

[55].United Nations.Department of Public Information. (2005). The millennium development goals report 2005. United Nations Publications.

[56]. Waweru KM (2003). Determining cash balance management practices: A case study of SACCOs in Nakuru district. Unpublished MBA project. Egerton University

[57].Yusuf, Y., Gunasekaran, A., \& Dan, G. (2007).Implementation of TQM in China and Organisation Performance: An Empirical Investigation. Total quality management, 18(5), 509-530. DOI: https://doi.org/10.1080/14783360701239982

\section{ACKNOWLEDGEMENTS}

First of all, I give thanks to God through whose grace I have made it this far. My heartfelt appreciation and indebtedness go to the Dean of School for his timely and effective advice throughout my research. Besides, I appreciate Mount Kenya University for offering me a platform to further my studies. Also, I appreciate all the respondents who took their time to participate in this study. 